$9^{\text {th }}$ International Scientific Conference

"Business and Management 2016"

May 12-13, 2016, Vilnius, LITHUANIA

http://www.bm.vgtu.lt
eISSN 2029-929X

eISBN 978-609-457-921-9

Article ID: bm.2016.09

http://dx.doi.org/10.3846/bm.2016.09

\title{
THIRD PARTY LOGISTICS COMPANIES' ACTIVITIES AND SELECTION METHODS
}

\author{
Aleksandrs Kotlars ${ }^{1}$, Valerijs Skribans ${ }^{2}$ \\ Faculty of Engineering Economics and Management, Riga Technical University, \\ Kalnciema street 6, Riga, LV1007, Latvia

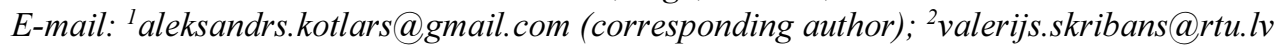

\begin{abstract}
The purpose of a study is to compare and assess 3PL companies' selection methods by researching evaluation criteria of 3PL companies and approaches of these criteria's classification used by companies who outsource logistics and transportation services to third parties. Objective of a study is, foremost, to investigate 3PL companies' selection methods proposed by leading specialists in field of logistics. Additionally, investigate operational activities, integration levels and core services provided by logistics companies in Europe with an emphasis on 3PL companies. The key finding of a study is that Multiple-criteria decision-making analyses are widely used in order to support strategic decision making in selection of 3PL companies.
\end{abstract}

Keywords: logistics systems, third party logistics, 3PL, logistics costs, logistics services, 3PL selection methods.

JEL Classification: L90; M16; R40; R41.

\section{Introduction}

In order to support continuous optimization process of logistics and transportation costs and simultaneously concentrate on core activities, many international businesses outsource part of their logistics functions to third party logistics (3PL) companies. This has become a widely used practice in international business due to wide scope of experience, knowledge and re-sources of 3PL companies, which allows providing transportation and logistics services with lower costs. The main reason of appearance and development of 3PL is considered to be high competition level among businesses in different industries. Under such circumstances, businesses are forced to continuously develop new products, as well as utilize the most efficient way of deliveries to their clients. Over the time 3PL companies has expanded their scope of services which allows them to cover large geographical areas and maintain wide range of product's transportation and storage. As businesses outsource part of logistics and transportation activities to third parties, 3PL companies are accurately assessed according to several criteria, which are unique for certain company and industry, e.g. level of prices, scope of available services, responsive-ness, financial wealth, reputation. Hence, as a process of strategic decision making, businesses have to systematically evaluate 3PL companies according to different criteria, considering both qualitative and quantitative parameters. The purpose of a study is to compare and assess selection methods of 3PL companies by researching evaluation criteria of 3PL companies and approaches of these criteria's classification used by companies who outsource logistics and transportation services to third parties. Objectives of a study are, foremost, to investigate $3 \mathrm{PL}$ companies selection methods proposed by leading specialists in field of logistics. Additionally, investigate and compare operational activities in different European countries, integration levels and core services provided by logistics companies with an emphasis on 3PL companies. To complete this study, different sources of information were used, including scientific works of leading specialists in field of logistics, Eurostat and international 3PL market research companies' databases. The main contribution of this study is identification and comparison of logistics companies' (with an emphasis on 3PL) de-velopment trends in different European coun-tries. Additionally, the description of how multiple-criteria decision-making (MCDM) analyses, which is widely used in many business areas, can be adjusted to 3PL companies' selection is provided.

\section{Definition of third party logistics companies}

In literature first references of logistics can be found in the end of nineteenth century. In the course of time, as manufacturing begun extensive develop- 
ment and new technologies appeared, e.g. in telecommunication industry, the number of companies specialized in cargo transportation and storage services has grown. In addition, their integration degree into management of clients' cargo transportation and storage has also increased (Sheikh, Rana 2014). Depending on degree of integration, there are four service levels that can be proposed by logistics companies.

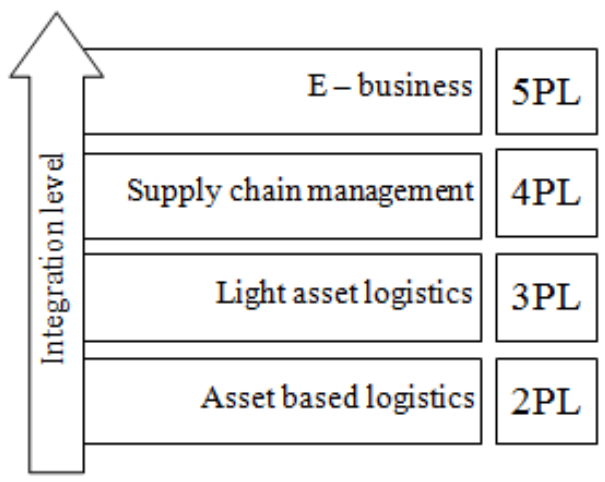

Fig. 1. Service levels of logistics companies (Source: McFarland 2014)

- 2PL - second party logistics (asset based logistics). This type of service is provided by companies that operate with own vehicles fleet and storage capacities. In fact, they contribute the major part of specialized logistics companies on market. In most cases, 2PL companies are able to provide exclusively traditional transportation and storage services, i.e. specialize in narrow scope of services and very often cooperate with third party logistics companies.

- 3PL - third party logistics (light asset logistics). There are different terms used to describe this type of logistics companies, e.g. forwarding company, logistics and transport operator, contract logistics company. However, there is vital difference between these terms. Services provided by forwarding companies are based on subcontracting. Simply speaking, these companies use their partners' assets (vehicles fleet, warehousing premises) in order to satisfy clients' demands. Meanwhile, logistics and transport operators are specialized in development and management of complex supply chains, including traffic planning, tariff building etc. Indeed, logistics and transport operators utilize 2PL companies' assets, but additionally integrate own solutions, e.g. IT tools, customer service and cargo tracing (Hongbo, Qilan 2008).
- 4PL - fourth party logistics (supply chain management). Similarly to 3PL, supply chain management is provided by light asset companies that utilize partners' vehicle fleet and warehousing premises. The main differences are scale of operations and integration level. 4PL companies usually cooperate with clients in large scale, i.e. managing several inbound and outbound flows of goods within region. The approach to selection and auditing of partners (subcontractors) is also different. 4PL companies, in addition to utilization of 2PL companies' assets, also attract 3PL companies' and their solutions. Usually services of 4PL companies are used by international companies, e.g. in automotive industry (Guojun 2008). Detailed comparison of 3PL and 4PL levels is provided in Table 1.

Table 1. Comparison of 3PL and 4PL integration levels (Source: Multaharju, Hallikas 2015; Saglietto 2013)

\begin{tabular}{|c|c|c|}
\hline $\begin{array}{l}\text { Characteris- } \\
\text { tics }\end{array}$ & $3 \mathrm{PL}$ & $4 \mathrm{PL}$ \\
\hline $\begin{array}{l}\text { Main tasks } \\
\text { and func- } \\
\text { tions }\end{array}$ & $\begin{array}{l}\text { Operational and } \\
\text { tactical func- } \\
\text { tion. Provision } \\
\text { of logistics and } \\
\text { transportation } \\
\text { activities activi- } \\
\text { ties with inte- } \\
\text { gration of value } \\
\text { added services. }\end{array}$ & $\begin{array}{l}\text { Strategic func- } \\
\text { tions. Supply } \\
\text { chain manage- } \\
\text { ment with ele- } \\
\text { ments of inte- } \\
\text { garation and } \\
\text { control of sup- } \\
\text { ply chain par- } \\
\text { ticipants. }\end{array}$ \\
\hline $\begin{array}{l}\text { Assets and } \\
\text { resources }\end{array}$ & $\begin{array}{l}\text { Light assests. } \\
\text { Managing 2PL } \\
\text { companies' } \\
\text { fleet and ware- } \\
\text { housing prem- } \\
\text { ises. Own logis- } \\
\text { tics IT, } \\
\text { transport and } \\
\text { warehousing } \\
\text { systems. }\end{array}$ & $\begin{array}{l}\text { Light assests. } \\
\text { Managing 2PL } \\
\text { companies' } \\
\text { fleet and ware- } \\
\text { housing, in ad- } \\
\text { dition integrate } \\
\text { 3PL companies' } \\
\text { performance } \\
\text { and systems. }\end{array}$ \\
\hline $\begin{array}{l}\text { Geographical } \\
\text { coverage }\end{array}$ & $\begin{array}{l}\text { National and re- } \\
\text { gional. Manag- } \\
\text { ing client's lo- } \\
\text { gistics flows in } \\
\text { narrow scope or } \\
\text { on defined } \\
\text { routes. }\end{array}$ & $\begin{array}{l}\text { Regional and } \\
\text { global. Manag- } \\
\text { ing client's lo- } \\
\text { gistics flows in } \\
\text { wide scope or } \\
\text { on defined busi- } \\
\text { ness segment. }\end{array}$ \\
\hline $\begin{array}{l}\text { Impact on } \\
\text { client's busi- } \\
\text { ness activi- } \\
\text { ties }\end{array}$ & $\begin{array}{l}\text { Influence flows } \\
\text { of goods (time } \\
\text { and place). }\end{array}$ & $\begin{array}{l}\text { Control and } \\
\text { plan flows of } \\
\text { goods. }\end{array}$ \\
\hline Performance & $\begin{array}{l}\text { Reduction of } \\
\text { client's logistics } \\
\text { costs. }\end{array}$ & $\begin{array}{l}\text { Value creation } \\
\text { within client's } \\
\text { organisation. }\end{array}$ \\
\hline
\end{tabular}


- 5PL - fifth party logistics (e-business). This level of integration, in addition to supply chain management, also foresees support to clients' commercial activities, e.g. selection of production materials suppliers (McFarland 2014).

There is another level of service, so called 1PL - first party logistics (producer's logistics), which was not previously mentioned due to the fact that by utilizing first party logistics, companies perform transportation and storage of goods using own assets. Taking into account high level of competition among in different industries, businesses are forced to continuously develop new products, as well as utilize the most efficient way of deliveries to their clients. However, despite this fact, some companies decide to utilize producer's logistics, justifying this with better experience in transportation and handling of own goods.

It is worth mentioning types and classification approaches of services provided by 3PL companies.

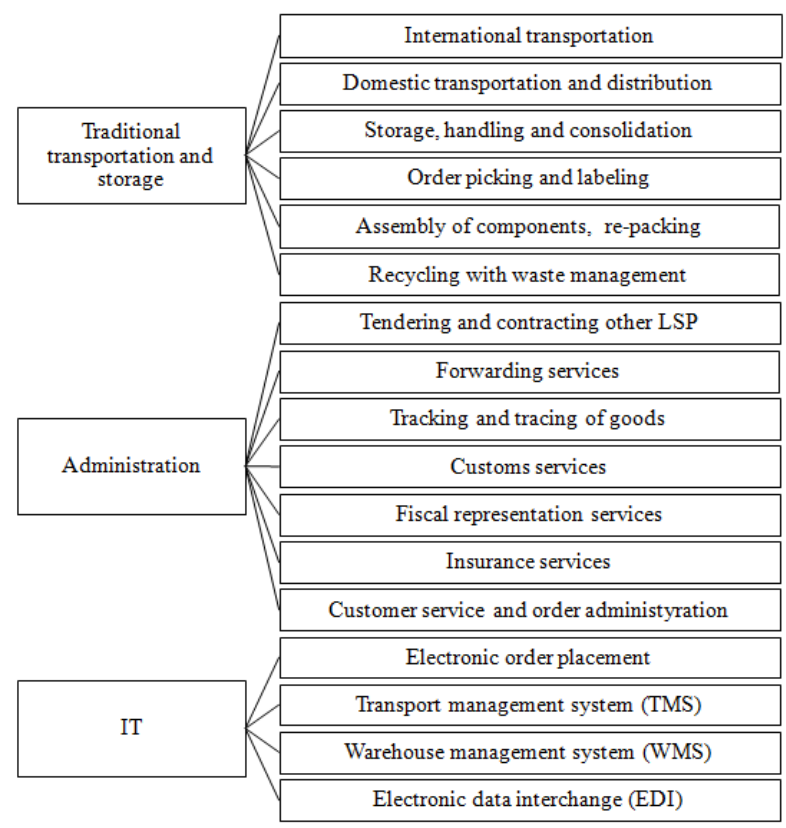

Fig. 2. Classification of 3PL services (Source: authors' illustration, adopted from Yang 2014, Vasilis Vasiliauskas, Barysiene 2008)

Figure 2 reflects division of 3PL companies' services into three groups. First group contains traditional transportation and storage services, i.e. physical handling of goods. Indeed, this group partly correspond to 2PL level, respectively, asset based logistics companies are also able to provide such type of services. Second group (administration) contains added-value services of 3PL companies, that make unique solution of supply chain management. Knowing the fact that term of 3PL appeared in the middle of 1970th, third group contains relatively new types of services that appeared in 1990th as a result of IT solutions' integration into logistics industry.

\section{Third party logistics companies' activities in EU}

According to statistical classification of economic activities in the European Community, there is dedicated transporting and storage division that contains variety of subdivisions, e.g. water transport, air transport, land transport etc. Considering 3PL companies' activities, it is necessary to keep in mind that these companies are able to provide intermodal and multimodal services. That is why, in order to identify 3PL company, it is necessary to investigate one's activities. Such type of researches are performed by supply chain management market research and consulting firms. It allows to evaluate dynamics of development of 3PL market within region.

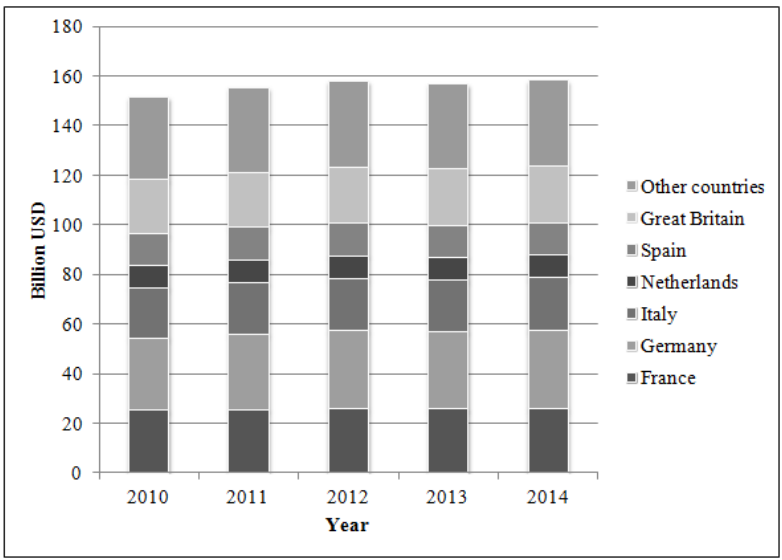

Fig. 3. Total turnover of 3PL companies in biggest EU countries (2010-2014, billion USD) (Source: authors' illustration using Armstrong \& Associates data 2014)

Figure 3 reflects dynamics of total turnover of largest 3PL companies in EU. In year 2014 the highest turnover was observed in Germany with an increase by $8.2 \%$ from year 2010 (29,3 billion USD) till year 2014 (31,7 billion USD). Second largest turnover was observed in France, where in year 2014 total turnover of 3PL companies reached 25,9 billion USD, which is by $3.2 \%$ more than in year 2010 ( 25,1 billion USD). Relatively low 4-years growth levels were registered in Italy (by $2.96 \%$ or by 0,6 billion USD), Spain (by $1.59 \%$ or by 0,2 billion USD) and Netherlands (by $3.33 \%$ or by 0,3 billion USD). In Great Britain during 4-year period 
there was 1 billion USD (by 4.57\%) turnover increase. Commercial activities of 3PL companies in rest of EU are compiled under category "other countries". In year 2014 total turnover reached 34,6 billion USD, which is by $3.9 \%$ more than in year 2010 (33,3 billion USD) (Armstrong \& Associates 2014).

In order to understand, how widely 3 PL service level is used, there is need to compare 3PL companies' turnover and total logistics costs of European companies.

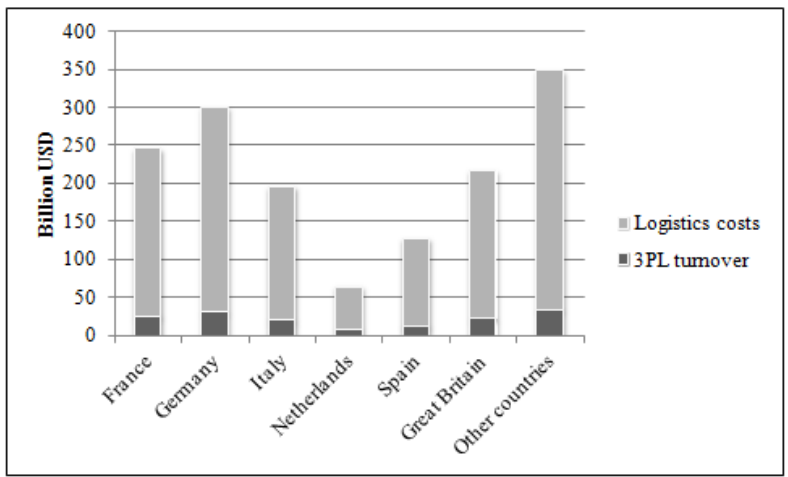

Fig. 4. Total logistics costs in biggest EU countries and turnover of 3PL companies (2014, billion USD) (Source: authors' illustration using Armstrong \& Associates data 2014)

According to Figure 4, in year 2014 highest companies' logistics costs were observed in Germany (301,5 billion USD). At the same time, German 3PL companies reached 25 billion USD turnover, which is $10.51 \%$ of total logistics costs. Second highest logistics costs were registered in France (246,8 billion USD), where share of 3PL turnover constituted $10.49 \%$. Great Britain is placed in third position with 218,3 billion USD of total logistics costs and similar to France share of 3PL companies' turnover $-10.49 \%$. In Netherlands there were lowest logistics costs registered in year 2014 (among these 6 countries), however, share of 3PL turnover constituted $14.31 \%$. Calculating average indicator all countries, results to $10,50 \%$ share of $3 \mathrm{PL}$ companies' turnover in total logistics costs. According to this, 3PL companies insure only slightly more than $10 \%$ of total demanded transportation and storage activities (Armstrong \& Associates 2014).

One of possible reasons why 3PL companies contribute relatively low share of market, could be the fact that in many cases 2PL service level is sufficient in order to insure clients' demand for transportation and storage activities. Keeping this in mind, it is worth to investigate dynamics of $2 \mathrm{PL}$ companies' development in EU and Baltic countries.

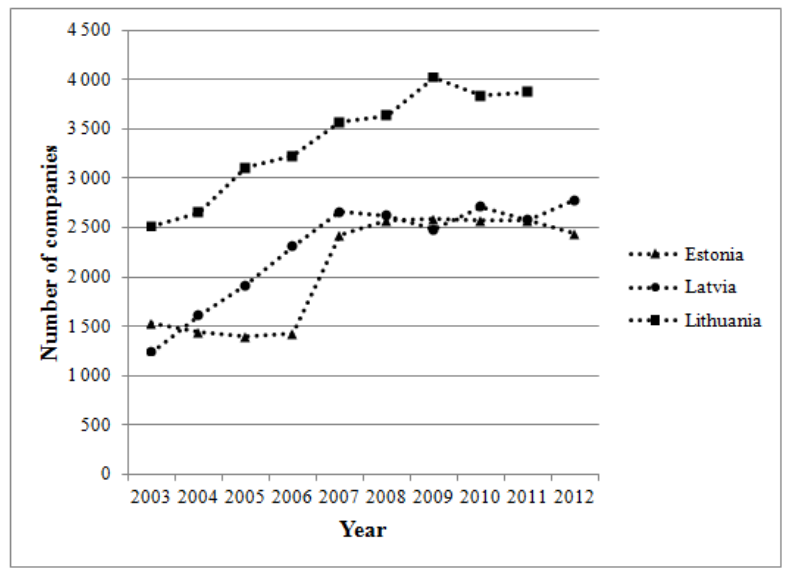

Fig. 5. Number of companies with own land fleet registered Baltic countries (2003-2012) (Source: authors' illustration using Eurostat data 2016)

Figure 5 reflects number of companies with own land fleet registered in each Baltic country from year 2003 till 2012. Totally, during 10 - year period, number of such companies in three countries has increased by $72.3 \%$, from 5278 to 9094 (2011 year data in Lithuania is taken). The most rapid growth was observed in Latvia - by $124.6 \%$ (from 1236 to 2776 ). In Estonia there was $60.12 \%$ growth (from 1527 to 2445). In Lithuania - by 54\% (from 2515 to 3873). Taking look into long term, during 15 -years period, there was $377 \%$ increase of own land fleet companies in Lithuania, $454 \%$ increase in Latvia and $68 \%$ increase in Estonia (from year 2000 till 2010). It is worth to mention that similar high dynamics is observed in following Eastern European countries: Bulgaria, Hungary and Rumania. In Bulgaria during 15-years period (from 1995 till 2010) number of companies with own land fleet increased by 8887 (from 185 till 9072). In Hungary by 15396 . In Romania during 14-years period (from 1995 till 2009) there was an increase by $241 \%$. At the same time, there is relatively slow dynamics observed in following Western European countries: Spain (by 3.67\% during 14-year period from 1995 till 2009) and France (-7.35\% during 15 -year period from 1995 till 2010) (Eurostat 2016).

\section{Selection methods of third party logistics companies}

The process of 3PL provider's selection contains several steps that are usually conducted by businesses. Depending on company's profile and its scope of activities, this procedure might take up to several months. Figure 6 reflects general milestones of selection process. 


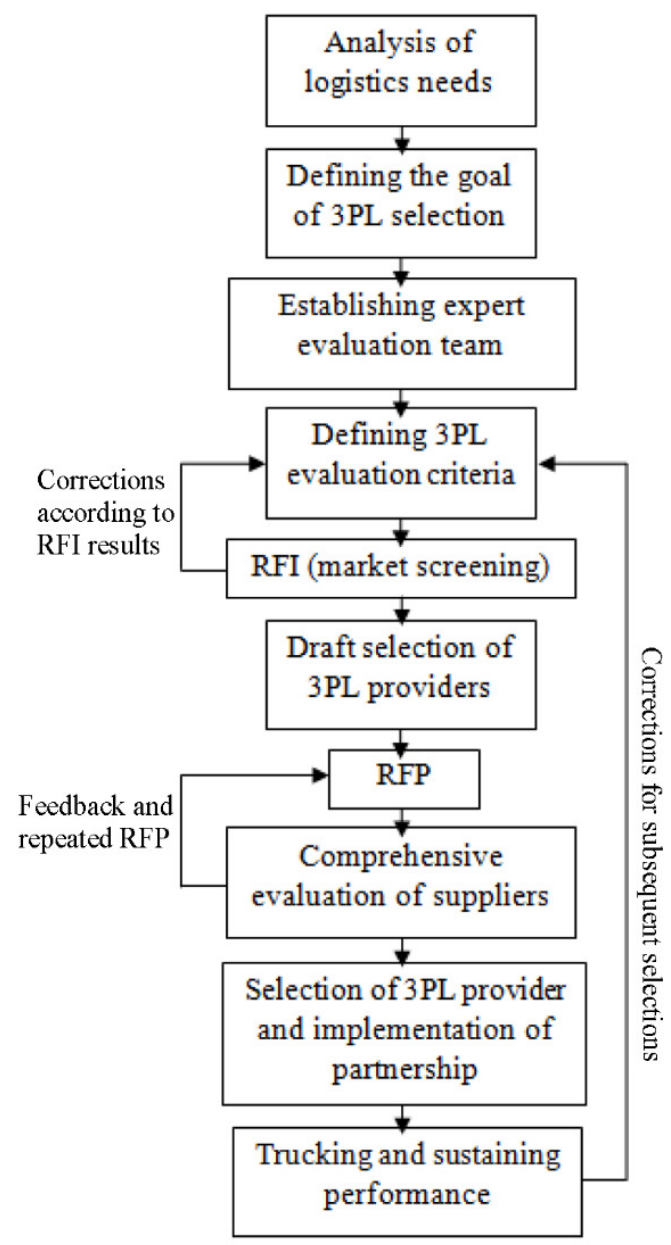

Fig. 6. Selection steps of 3PL provider (Source: adopted from Guoyi, Xiaohua 2012; Botanni, Rizzi 2006)

The first steps conducted by businesses are analysis of needs and definition of goal. According to defined goal (e.g. to acquire full truck load and full container load cross border transportation services within Europe), decision concerning involvement of particular 3PL providers, who might correspond company's needs, shall be made. Expert team, which is often named performance evaluation team, consists of company's procurement personnel in charge of evaluation and ranking involved 3PL providers according to defined criteria. One of key important steps is definition of 3PL evaluation criteria. These criteria will be used by performance evaluation team in scope of particular selection method. First involvement of potential 3PL provider is so called request for information (RFI) or market screening. As the result of this activity, following information about 3PL providers can be gathered: interest and capabilities to provide requested services; contact information; quality certification; information technology systems capabilities; fleet size etc. As soon, as RFI is completed, draft selection of most suitable 3PL providers is conducted and request for proposal (RFP) is implemented. During RFP phase 3PL providers are asked to make commercial proposals according to company's defined needs. In practice, there may be several RFP rounds, so 3PL providers are able to make adjustments in their commercial proposals according to given feedbacks. Comprehensive evaluation of suppliers is done by performance evaluation team. There are various methods mentioned in literature and used by leading specialists. These methods will be later described in this article. Final steps are selection of most suitable 3PL provider, implementation of partnership and sustaining performance. It is necessary to mention that trucking of selected provider's performance is very crucial due to the fact that it will allows to implement corrections in evaluation criteria for subsequent selections.

The key challenge usually faced by businesses in frames of 3PL providers' selection process is utilization of systematic approach, which would allow taking into account and equally treating both qualitative and quantitative criteria of evaluation. As a result of literature research, it is proposed to emphasize four categories of methods used by industry's leading specialists.

First group contains exclusively qualitative methods. The main idea of these methods is utilization of objective and subjective criteria for 3PL providers' ranking. In scope of selection process, very often questionnaire among potential 3PL providers is conducted (request for information). Afterwards, evaluation factors are structured according to service quality model (e.g. RATER - reliability, assurance, tangibles, empathy, and responsiveness). In this case, selection factors are considered from 3PL provider's perspective, its capabilities and willingness to cooperate.

- Reliability: this group contains factors that show ability of 3PL provider to dependably perform according to promised level of service. As an example, company's reputation can be mentioned that could be determined by means of conducted questionnaire;

- Assurance: this group contains factors that show provider's employees knowledge in particular service. It is usually investigated by businesses in frames of selection process (see Fig. 6) during face-to-face meetings when short listed 3PL providers are invited to present their logistics solutions;

- Tangibles: the appearance of equipment, physical facilities, personnel and other communication materials are included in this group. Knowing that 3PL providers are considered to be light asset companies, such 
benefits and its' integration into supply chain could be examined by businesses: IT systems, e.g. TMS, WMS (see Fig. 2), existence of online order placement service, reporting systems etc;

- Empathy: these factors are aimed to help businesses to understand how potential 3PL provider is keen to be involved in improvement of logistics processes of client. As an example, in frames of selection process, businesses might evaluate innovative approach or logistics solutions of 3PL providers;

- Responsiveness: these factors show potential 3PL proveders' willingness to help client and to provide prompt service. For instance, potential partner's behaviour and proactivity during selection process, as well as availability of dedicated customer service might be considered as great advantage (Snimkova et al. 2015).

It is also possible to find other frameworks, e.g. evaluation factors may be divided into three groups - contextual, uncertainty and implementation. It is important to mention that selection factors divided among these groups are considered from client's perspective and it's ability to directly or indirectly influence them.

- Contextual factors: these factors are considered to be the basis for successful selection of $3 \mathrm{PL}$ provider. However, they are not changeable or even not under control of client. As an example, following factors can be mentioned: 3PL partner's reputation on market, company's size and age, ownership;

- Uncertainty factors: this group contains factors that potentially might be under control of client or at least partially influenced. With the reference to previously described selection process (see Fig. 6), after nomination of 3PL provider and implementation of partnership, trucking and sustaining of performance is conducted. As a result of these activities, client in cooperation with provider is able to fine - tune uncertainty factors. Following factors are included in this group: 3PL partner's dispute solving approach, behaviour of people within provider's organization; provider's ability to be constantly updated to new technologies;

- Implementation factors: these are critical factors that client has to take into account in order to select most appropriate 3PL partner. Basically, they reflect competitiveness of particular 3PL provider. Furthermore, these factors are considered to be under control of client and can be completely influenced during selection process. With the reference to 3PL selection steps (see Fig. 6), influence can be seen as potential 3PL providers receive client's feedback after recurrent RFP stage with recommentadions for improvement. Following factors are included in this group: price level offered by 3PL provider, service quality including transportation lead time, proposed bonusmalus system, provider's responsiveness to client's requests, understanding client's supply chain needs, support from 3PL provider's top management etc.) (Rattanawiboonsom 2014).

It is necessary to admit that qualitative methods are relatively flexible to businesses' preferences and usually conducted by expert team.

Second group contains exclusively quantitative methods. There are many researches held with purpose to define advantages and disadvantages of particular quantitative method. It is important to note that in order to make decision of 3PL provider's selection using quantitative method, precise evaluation criteria shall be defined. These criteria are unique for particular industry and business. It is worth mentioning following quantitative evaluation methods, which are widely used in literature:

- Analytical hierarchy process (AHP) and analytical network process (ANP). In frames of this method, three elements of analysis are defined (see Fig. 7). Firstly, there is goal defined (selection of most appropriate 3PL provider). Secondly, evaluation criteria used for analysis are defined. Thirdly, alternatives (potential 3PL providers). In scope of analysis, first of all, providers are compared pair wise according to each of previously defined evaluation criteria and priority coefficients are created (comparison of criteria and alternatives). Second step is to compare all evaluation criteria pair wise and create priority coefficients (comparison of goal and criteria). Finally, above mentioned coefficients are combined into single matrix and highest ranked 3PL provider is selected (Chunling et al. 2010; Wang, Liu 2007; Ke et al. 2010).

- Technique for order of preference by similarity to ideal solution (TOPSIS). The idea of this method is similar to AHP and ANP. At the early stage of analysis evaluation criteria are defined, potential 3PL providers are selected and priority coefficients are created. Afterwards, priority coefficients 
are compared according to two artificial hypothesis - best and worst possible (Qureshi et al. 2007).

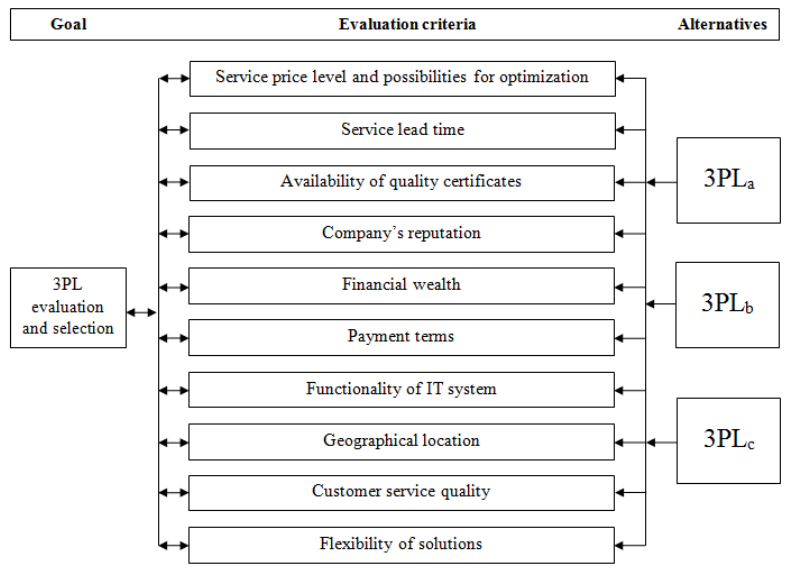

Fig. 7. ANP and AHP elements of analysis (Source: authors' illustration, adopted from Gupta, Somwanshi 2014)

- Classification of potential 3PL providers from the best one to the worst using ELECTRE method. This method aims to structure alternatives (potential 3PL providers) by evaluation of conformities and non-conformit et al. 2007; Govindan, Grigore 2010).

- Quality function deployment (QFD) method. This method aims to transform company's service demands (qualitative criteria) into technological requirements (quantitative criteria) (Guo et al. 2010).

Third group contains a mix of qualitative and quantitative methods for 3PL selection, i.e. approaches that include both qualitative analysis and quantitative inferences. Analysis usually starts by performing questionnaire with purpose to define and structure evaluation criteria. The key advantage of these methods mentioned by industry's specialists is broad range of evaluation criteria that can be used in frames of analysis.

Forth group provides inference of fuzzy approach into 3PL provider's selection. Fuzzy logic is widely used in combination with AHP and ANP methods. It allows company's experts to utilize gradual evaluation of particular 3PL provider according to each of defined criteria. Integration of fuzzy approach is especially valuable if qualitative criteria (e.g. 3PL partner's reputation) shall be transformed into quantitative data (Zhang, Feng 2007; Jindal, Sangwan 2013). It is necessary to admit that majority of 3PL evaluation criteria cannot be easily quantified that is why company's experts have to compile different gradations.

\section{Discussion and conclusions}

The main contribution of this article is research and classification of 3PL companies' selection methods utilized by leading specialists in practice of international business. Firstly, this allows defining main differences between above mentioned methods. Secondly, realize key advantages and disadvantages of application of MCDM to selection of 3PL provider. Thirdly, provides opportunity for future studies to develop hybrid methods by combining elements of already known approaches.

As the result of investigation of qualitative 3PL provider's selection methods, different approaches of structuring of evaluation factors are discovered. These factors can be viewed by businesses from two dimensions:

- 3PL provider and its values. In this case, factors are structured and evaluated according to provider's capabilities to perform and willingness to cooperate with client.

- Client and its influence on provider. In this case, factors are structured and evaluated according to client's ability to control performance of 3PL provider.

Multiple-criteria decision-making, which is widely applied in different areas of business, is also often used as a tool of strategic decision making in logistics and procurement (Montibeller, Franco 2010). According to number of researches done by leading specialists in logistics industry, it is found that methods of MCDM can be classified into four groups: exclusively qualitative, exclusively quantitative, mixed and fuzzy. The main advantage of utilizing multiple-criteria decision-analysis to select 3PL provider is possibility to compile qualitative and quantitative criteria of 3PL provider's evaluation. The main disadvantage of this analysis is relatively sophisticated process of evaluation that, in addition to logistics and procurement experts, may require involvement of business analysts.

Based on review of 3PL companies' activities in EU, it is found that, despite the fact of high integration level, these companies provide slightly more than $10 \%$ of total demanded transportation and storage services in region. Hence, majority of logistics operations are performed whether by 2PL companies, or producers' logistics (1PL). It is concluded that 2PL level remains much demanded in EU, which is confirmed by the increasing number of companies with own land fleet, especially in Eastern European countries. 


\section{References}

Aguezzoul, A.; Rabenasolo, B.; Jolly-Desodt, A. M. 2007. Multicriteria decision aid tool for third-party logistics providers' selection. IEEE. 1-4244-0451-7/06.

Armstrong \& Associates, Inc. 2014. Global and regional infrastructure, logistics costs, and thirdparty logistics market trends and analysis [online], [cited 15 February 2016 ]. Available from Internet: http://www.3plogistics.com/Global_3PL_Market Analysis_EIS-2014.pdf

Botanni, E.; Rizzi, A. 2006. A fuzzy TOPSIS methodology to support outsourcing of logistics services, Supply Chain Management: An International Journal 11: 294-308.

Chunling, S.; Yongming, P.; Ran, B. 2010. Study on third-party logistics service provider selection evaluation indices system based on analytic network process with BOCR. IEEE. 978-1-4244-7330-4/10.

Govindan, K.; Grigore, C. 2010. Ranking of third party logistics provider using fuzzy Electro II, in $40^{\text {th }} \mathrm{In}$ ternational Conference on Computers and Industrial Engineering, 26-28 July 2010, Awaji, Japan. IEEE. 978-1-4244-7295-6.

http://dx.doi.org/10.1109/ICCIE.2010.5668366

Guo, Y.; Feng, Y. 2010. Performance evaluation of thirdparty logistics enterprises based on QFD, in $3^{r d} I n-$ ternational Conference on Information Management, Innovation Management and Industrial Engineering, 26-28 November 2010. 978-0-7695-4279$9 / 10$.

Guoyi, X.; Xiaohua, C. 2012. The third party logistics supplier selection and evaluation, Journal of software 7(2): 1783-1790.

Guojun, J. 2008. Study on 4PL as coordinating and constructing agent for supply chain system - a transaction cost theory approach, in International Conference on Service Systems and Service Management, 30 June - 2 July 2008, Melbourne, VIC, IEEE, 9781-4244-1672-1/08.

Gupta, M.; Somwanshi, D. K. 2014. Selection \& implementation of component in component based development using analytical network process, in International Conference on Green Computing Communication and Electrical Engineering, 6-8 March 2014, Coimbatore, India. IEEE.

Hongbo, Q.; Qilan, Z. 2008. Research o third party logistics service capability maturity model, in Internationl Conference on Service Operations and Logistics, and Informatics, 12-15 October 2008, Beijing, China, IEEE. 978-1-4244-2012-4.

Jindal, A.; Sangwan, K. S. 2013. An integrated fuzzy multi - criteria evaluation of sustainable reverse logistics network models, in IEEE International Conference on Fuzzy Systems, 7-10 July 2013, Hyderabad, India. IEEE. 978-1-4799-0020-6.

Ke, F.; Jiayan, X.; Qun, Z.; Zhaowei, M. 2010. An AHP based decision support model for 3PL evaluation, in $7^{\text {th }}$ International Conference on Service Systems and Service Management (ICSSSM), 28-30 June 2010, Tokyo, Japan. IEEE. 978-1-4244-6485-2.

McFarland, K. 2014. Market analysis - 2014-2019 trends-corporate strategies. Xerfi Global, 206 p.

Montibeller, G.; Franco, A. 2010. Multi-criteria decision analysis for strategic decision making, in Zopounidis, C.; Pardalos, P. M. Handbook of multicriteria analysis. Springer, 25-45. ISBN 978-3540-92827-0.

Multaharju, S.; Hallikas, J. 2015. Logistics service capabilities of logistics service provider, International Journal of Logistics Systems and Management, 20(1): 103-121. http://dx.doi.org/10.1504/IJLSM.2015.065975

Qureshi, M. N.; Kumar, D.; Kumar, P. 2007. Selection of potential 3PL services providers using TOPSIS with interval data. IEEE. 1-4244-1529-2/07.

Rattanawiboonsom, V. 2014. Effective criteria for selecting third-party logistics providers: the case of Thai automotive industry, World Review of Business Research 4(2): 196-205.

Saglietto, L. 2013. Towards a classification of fourth party logistics (4PL), Universal Journal of Industrial and Business Management 1(3): 104-116.

Sheikh, Z.; Rana, S. 2014. The role of logistics service providers in supply chain management: a comprehensive literature review, International Journal of Academic Research in Business and Social Sciences 4(5): 608-613.

Snimkova, E.; Niko, E.; Kolar, P.; Hunak, J. 2015. Decision-making factors leading to customers' satisfaction in container transportation, in $4^{\text {th }}$ IEEE International Conference on Advanced Logistics and Transport, 20-22 May 2015, Valenciennes, France. IEEE. 978-1-4799-8400-8/15.

Vasilis Vasiliauskas, A.; Barysiene, J. 2008. Review of current state of European 3PL market and its main challenges, Computer Modelling and New Technologies 12(2): 17-21.

Wang, Y.; Liu, Y. 2007. Research on the evaluation and selection of partner in logistics strategic alliance based on AHP-TOPSIS, in $14^{\text {th }}$ International Conference on Management Science \& Engineering, 20-22 August 2007, Harbin, China.

Yang, X. 2014. Status of third party logistics - a comprehensive review, Journal of Logistics Management 3(1): 17-20.

Zhang, Y.; Feng, Y. 2007. A selection approach of reverse logistics provider based on fuzzy AHP, in Fourth International Conference on Fuzzy Systems and Knowledge Discovery, 24-27 August 2007, Haikou, China,

Eurostat. Goods road transport enterprises, by number of vehicles [online], [cited 15 February 2016]. Available from Internet: http://ec.europa.eu/eurostat/data/database 